\section{(6) OPEN ACCESS}

SHORT REPORT

\title{
Condoms for prisoners: no evidence that they increase sex in prison, but they increase safe sex
}

\author{
Tony Butler, ${ }^{1}$ Juliet Richters, ${ }^{2}$ Lorraine Yap, ${ }^{1}$ Basil Donovan ${ }^{1,3}$
}

\begin{abstract}
${ }^{1}$ Kirby Institute, University of New South Wales, Sydney, New South Wales, Australia ${ }^{2}$ School of Public Health and Community Medicine, University of New South Wales, Sydney, New South Wales, Australia

${ }^{3}$ Sydney Sexual Health Centre, Sydney Hospital, Sydney, New South Wales, Australia
\end{abstract}

\section{Correspondence to} Professor Tony Butler, The Kirby Institute, UNSW Medicine, University of New South Wales, Sydney, NSW 2052, Australia; tbutler@kirby.unsw.edu.au

Received 02 October 2012 Revised 06 December 2012 Accepted 09 December 2012 Published Online First

7 January 2013

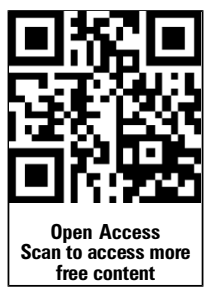

To cite: Butler T, Richters J, Yap L, et al. Sex Transm Infect 2013;89:377-379.

\section{ABSTRACT \\ Objectives To determine if the provision of condoms} to prisoners in two Australian state prison systems with different policies affects sexual behaviour. In New South Wales' (NSW) prisons, condoms are freely distributed, while in Queensland prisons none are distributed. Methods We used a computer-assisted telephone interview to survey randomly selected prisoners in both states about their sexual behaviour in prison.

Results Two thousand and eighteen male prisoners participated. The proportion of prisoners reporting anal sex in prison was equally low in NSW (3.3\%) and Queensland (3.6\%; $p=0.8)$. A much higher proportion of prisoners who engaged in anal sex in NSW $(56.8 \%)$ than Queensland $(3.1 \% ; p<0.0001)$ reported they had used a condom if they had had anal sex in prison. Sexual coercion was equally rare in both prison systems. Conclusions We found no evidence that condom provision to prisoners increased consensual or non-consensual sexual activity in prison. If available, condoms were much more likely to be used during anal sex. Condoms should be made available to prisoners as a basic human right.

\section{INTRODUCTION}

Earlier, we reported that the introduction of condoms into New South Wales (NSW, Australia) prisons in 1996 did not lead to many of the adverse events that had been predicted. ${ }^{1}$ Condoms were introduced into NSW prisons following a class action by prison inmates. Despite this evidence, the provision of condoms to prisoners remains contentious and is uncommon globally, ${ }^{2}$ even though condoms are known to be effective in reducing the spread of HIV and other sexually transmissible infections. $^{3}$

Opponents (including some prisoners) argued that condoms might: (a) encourage prisoners to have sex, (b) increase rape in prison by providing sexual predators with protection against infection or leaving DNA evidence, (c) be used as weapons against custodial staff, (d) give the perception that most prisoners were homosexual, and (e) lead to prisons being seen to condone promiscuity and homosexuality. Following an exhaustive search by the NSW Department of Corrective Services over a 10 -year period, only three official incidents could be found of a condom being inappropriately used. ${ }^{1}$ However, prisoners in NSW do report using condom kits (containing a condom, lubricant, instructions on usage-all inside a plastic bag) for myriad non-sexual purposes, such as storing tobacco, contraband and other items, and hair ties. ${ }^{45}$ The lubricant was used as a shaving aid, as hair gel, and-when flavoured lubricant was available-to make milk-shakes and to spread on bread. ${ }^{1}$ Most male prisoners report negative attitudes toward male homosexuality. ${ }^{6}$

In this paper, we compare levels of consensual and non-consensual sexual activity as reported in the Sexual Health and Attitudes of Australian Prisoners (SHAAP) survey, ${ }^{5}$ and the use of condoms in two state prison systems, one that freely provides condoms to prisoners (NSW) and one that does not (Queensland).

\section{METHODS}

We surveyed representative samples of prisoners in NSW and Queensland about their sexual behaviour, attitudes to sex and knowledge of sexually transmissible infections. ${ }^{5-7}$ We chose these states because NSW freely distributes around 30000 condoms per month to its prisoners, while Queensland distributes none. These two states combined, house around $60 \%$ of Australia's prisoners.

The methods for the survey have been published elsewhere in detail. ${ }^{5}{ }^{7}$ Briefly, potential participants were randomly selected from a list of all inmates at a particular prison provided by the two Departments of Corrective Services. Those selected were provided with a verbal explanation of the study by a recruiter and given a printed information sheet and consent form to sign. Participants were reassured that the phone call would not be recorded or electronically eavesdropped upon by prison authorities, and that they could withdraw at any time without consequence. Each participant received \$A10 as compensation for time lost while engaged in paid work in the prison.

Computer-assisted telephone interviews were conducted by a private social market research company, and took place in a private space; for instance, a legal visits room or consulting room in the health clinic. Interviews lasted, on average, about 30 minutes. $\chi^{2}$ Statistics were used to compare proportions.

\section{RESULTS}

A total of 2018 prisoners responded for a response rate of $76.8 \%$ (range $60 \%$ to $100 \%$ ). At the time of the survey, 9500 men were in full-time custody in NSW prisons, and 5100 men were in Queensland prisons. ${ }^{8}$ We found that condom provision was not associated with higher levels of sexual activity. Indeed, slightly more prisoners in Queensland $(8.8 \%)$ than NSW $(5.8 \% ; p=0.01)$ reported sexual activity in prison (see table 1). Overwhelmingly, the reported sexual activity in both states was consensual 
Table 1 Sexual activity reported by male prisoners in New South Wales and Queensland, Australia

\begin{tabular}{|c|c|c|c|}
\hline \multirow[b]{2}{*}{ Characteristic } & \multirow{2}{*}{$\begin{array}{l}\text { Condoms available to prisoners } \\
\text { New South Wales }(n=1118)\end{array}$} & \multirow{2}{*}{$\begin{array}{l}\text { No condoms available to prisoners } \\
\text { Queensland }(n=900)\end{array}$} & \multirow[b]{2}{*}{ p Value } \\
\hline & & & \\
\hline \multicolumn{4}{|l|}{ Ever had sexual contact in prison with inmate ${ }^{*}, \dagger$} \\
\hline Yes $(\%)$ & $65(5.8)$ & $79(8.8)$ & \multirow[t]{4}{*}{0.01} \\
\hline No $(\%)$ & 1045 (93.5) & $820(91.1)$ & \\
\hline Refused to answer (\%) & $1(0.1)$ & - & \\
\hline No sexual experience at all (in prison or the community) (\%) & $7(0.6)$ & $1(0.1)$ & \\
\hline \multicolumn{4}{|l|}{ Sexual partners in prison (if had sex in prison) } \\
\hline Median number (range) & $2(1-50)$ & $2(1-2500)$ & 0.9 \\
\hline \multicolumn{4}{|l|}{ Sexually coerced in prisont, $\neq$} \\
\hline Yes (\%) & $27(2.4)$ & $26(2.9)$ & \multirow[t]{3}{*}{0.5} \\
\hline No $(\%)$ & $1084(97.0)$ & $873(97.0)$ & \\
\hline Missing (\%) & $7(0.6)$ & $1(0.1)$ & \\
\hline \multicolumn{4}{|l|}{ Ever threatened with sexual assault in prisont } \\
\hline Yes (\%) & $64(5.7)$ & $75(8.3)$ & \multirow[t]{3}{*}{0.05} \\
\hline No $(\%)$ & $1053(94.2)$ & $823(91.4)$ & \\
\hline Not sure $(\%)$ & $1(0.1)$ & $2(0.2)$ & \\
\hline \multicolumn{4}{|l|}{ Ever had anal sex in prisont } \\
\hline Yes (\%) & $37(3.3)$ & $32(3.6)$ & \multirow[t]{2}{*}{0.8} \\
\hline No (\%) & $1081(96.7)$ & $868(96.4)$ & \\
\hline \multicolumn{4}{|c|}{ Ever used condom for anal sex with another prison inmate (if had sex in prison) } \\
\hline Yes $(\%)$ & $21(56.8)$ & $1(3.1)$ & \multirow[t]{3}{*}{$<0.0001$} \\
\hline No $(\%)$ & $7(18.9)$ & $25(78.1)$ & \\
\hline Missing (\%) & $9(24.3)$ & $6(18.8)$ & \\
\hline \multicolumn{4}{|l|}{ Consented to first sexual contact in prison (if had sex in prison) } \\
\hline Yes (\%) & $54(83.1)$ & 70 (88.6) & \multirow[t]{3}{*}{0.5} \\
\hline No $(\%)$ & $10(15.4)$ & $7(8.9)$ & \\
\hline Equivocal (\%) & $1(1.5)$ & $2(2.5)$ & \\
\hline
\end{tabular}

and consisted mostly of manual or oral sex. ${ }^{79}$ The proportion of prisoners reporting anal sex in prison was equally low in NSW $(3.3 \%)$ and Queensland $(3.6 \% ; \mathrm{p}=0.8)$. A much higher proportion of prisoners who engaged in anal sex in NSW $(56.8 \% \mathrm{v}$ $3.1 \% ; \mathrm{p}<0.0001)$ reported they had used a condom if they had had anal sex in prison (see table 1). Sexual coercion was equally rare in both prison systems (see table 1 ).

\section{DISCUSSION}

These findings demonstrate that providing prisoners with condoms is not associated with an increase in consensual or non-consensual sexual activity, or even threats of sexual assault. Hardly surprisingly, we have demonstrated that condoms are much more likely to be used for anal sex if they are available, but the likelihood of anal sex is not increased. Despite the widespread acceptance of condoms in the community, their

\section{Key messages}

- We found no evidence that providing condoms to prisoners increases consensual or non-consensual sexual activity in prison.

- If available, condoms were much more likely to be used by prisoners during anal sex.

- Condoms should be made freely available to all prisoners as a basic human right. introduction into prisons remains controversial and uncommon, ${ }^{2}$ even though the arguments used to oppose condoms in prison have no empirical evidence to support them, as others and we have found. ${ }^{1}{ }^{10}$ Civilised societies owe their prisoners a duty-of-care, including the right to protect themselves during sexual activity.

Limitations of the SHAAP survey include: the use of selfreport and the possibility that some respondents may have under-reported both consensual sex and sexual assaults. We used a broad definition of sexual assault ranging from unwanted touching or kissing, to rape, which have inflated the numbers of prisoners reporting sexual assault. Similarly, we had no information on structural issues which may have influenced sexual activity, such as housing in single cells and prison officer supervision levels.

As advocated by WHO, the United Nations, the American Public Health Association and the Public Health Association of Australia, we believe that condoms should be made freely available in prisons. ${ }^{11}$

Acknowledgements We are most grateful to the prisoners who freely and willingly provided us with intimate details of their lives in the hope that this research can help to better understand the sexual health of this group. We are grateful to the following who provided valuable input to the development of the study: Dr Tony Falconer, Max Saxby, Fred Ropp, Jenny Douglas, Joanne Holden, Ariane Minc, Debbie Pittam and the members of the study reference group for help in the early stages. Dr Alun Richards and Mr Luke Grant assisted in the development of the SHAAP survey.

Contributors $T B, B D, J R$ and $L Y$ were all responsible for the study design and writing the manuscript. TB was responsible for data analysis. 
Funding This work was supported by the National Health and Medical Research Council grant number 350860 .

Competing interests None.

Ethics approval Approval was independently granted by the NSW Justice Health Human Research Ethics Committee (GEN5/05), the University of New South Wales Human Research Ethics Committee (HREC 05045), the NSW Department of Corrective Services Ethics Committee (Ref 05/0882) and the Queensland Corrective Services Research Committee.

Provenance and peer review Not commissioned; externally peer reviewed.

Open Access This is an Open Access article distributed in accordance with the Creative Commons Attribution Non Commercial (CC BY-NC 3.0) license, which permits others to distribute, remix, adapt, build upon this work non-commercially, and license their derivative works on different terms, provided the original work is properly cited and the use is non-commercial. See: http://creativecommons.org/ licenses/by-nc/3.0/

\section{REFERENCES}

1 Yap L, Butler T, Richters J, et al. Do condoms cause rape and mayhem? The long-term effects of condoms in New South Wales prisons. Sex Transm Infect 2007;83:219-22.

2 Spaulding A, Lubelczyk RB, Flannigan T. Can unsafe sex behind bars be banned? Am J Public Health 2001;91:1176-7.
3 Holmes KK, Levine R, Weaver M. Effectiveness of condoms in preventing sexually transmitted infections. Bull World Health Organ 2004;82:454-61.

4 Butler T, Milner L. The 2001 Inmate Health Survey. Sydney: NSW Corrections Health Service, 2003. ISBN: $073473560 \mathrm{X}$.

5 Butler T, Richters J, Yap L, et al. Sexual health and behaviour of Queensland prisoners with Queensland and New South Wales comparisons. Perth: National Drug Research Institute and School of Public Health and Community Medicine (University of New South Wales), 2010. ISBN: 978-0-9807054-0-9.

6 Malacova E, Butler T, Richters J, et al. Attitudes towards sex: a comparison of prisoners and the general community. Sex Health 2011;8:355-62.

7 Butler T, Malacova E, Richters J, et al. Sexual behaviour and sexual health of Australian prisoners. Sex Health Published Online First: 21 December 2012. doi:10.1071/SH12104.

8 Prisoners in Australia. Catalogue No. 4517.0. Canberra: Australian Bureau of Statistics, 2007.

9 Richters J, Butler T, Schneider K, et al. Consensual sex between men and sexual violence in Australian prisons. Arch Sex Behav 2012:41:517-24.

10 Sylla M, Harawa N, Resnick 0 . The first condom machine in a US Jail: the challenge of harm reduction in a law and order environment. Am J Public Health 2010;100:982-5.

11 Evidence for action on HIVIAIDS and injecting drug use. Policy Brief: Reduction of HIV Transmission in Prisons. World Health Organization. UNAIDS. United National Office on Drugs and Crime. 2004. 